\title{
A EVOLUÇÃO URBANA DURANTE A ALTA IDADE MÉDIA (1).
}

Que entendemos por problema urbano da Alta Idade Média? $E^{\prime}$ tradicional focalizá-lo quase ùnicamente no Nordeste da Europa, na França, nos Países-Baixos, na Inglaterra; e assim focalizado, êle se inscreve entre dois fatos irrefutáveis que têm um ponto de partida e um ponto de chegada muito nítidos. Originalmente, uma decadência urbana que começou com a crise econômica do Império Romano no III século e que marcou o desaparecimento da cidade antiga, das instituiçōes urbanas e do gênero de vida urbana no Ocidente - que se barbarizou e se ruralizou cada vez mais. No outro ponto, uma restauração urbana, que se notou no Ocidente a partir dos séculos X e XI. As cidadesi e as formas urbanas ai reapareceram, esporádicas inicialmente, depois cada vez mais densas. O movimento se espalhou progressivamente e a cioade tomou a forma, chamada pròpriamente, de cidade medieval. Todavia, essa cidade medieval, mesmo quando parece renascer das cinzas da cidade antiga e se instala sôbre o mesmo local desta ou na sua proximidade, apresenta características muito diferentes.

A cidade romana se nos apresenta sob a forma de um núcleo monumental, muito concentrado, onde se congregam o forum, o templo e o pretório. Todo o resto do espaço urbano que se chama a cidade antiga, mostra um plano em ordem dispersa: "vilas" e cabanas, jardins e culturas formann uma zona urbana mal delimitada; não há muralha para estabelecer uma separação material entre a cidade e o campo, o arrabalde (faubourg) não existe. A noção de arrabalde (faubourǵ) é uma noção medieval; é aquilo que está além da muralha urbana. Na cidade romana, pelo contrário, tem-se a impressão duma extensão indefinida de novos bairros de residência. E' assim que se apresenta a cidade antiga, tôda impregnada da vida rural. Essa cidade romana, no Ocidente, é habitada por funcionários e por proprietários de terras que vivem, seja de seus emolumentos, seja dos rendimentos de suas terras, isto

\footnotetext{
(1). - Esta rápida síntese é o resuitado de conceitos emitidos numa conferência feita em março de 1951 na Universidade de Toulouse (França) para a Associação Mare Bloch e a Sociedade de Professôres. de Históra. Ela é o ponto de partida e o primeiro esbôço duma obra sôbre as cidades da Alta Idade Média atualmente em preparação. Texto francês traduzido por E. Simões de Paula (Nota da Redação).
} 
-é, do campo vizinho. E são êsses proprietários de terras, senhores do campo, que formam o elemento dirigente, o elemento rico da cidade antiga. E' necessário notar também a presença de artífices e de mercadores, atraídos pelas maiores possibilidades dos mercados de consumo que então se abrem. Portanto, uma cidade administrativa e militar, originalmente pelo menos, cidade criada ao longo das estratégicas vias romanas e sobretudo nos seus cruzamentos e também ao longo das antigas rotas gaulesas que existiam antes da rêde de vias romanas. Um pequeno comércio e uma pe- quena indústria citadina não tardam a se desenvolver aí para as necessidades dessa população de administradores e de militares. Depois, os proprietários dos arredores vieram se instalar na nova aglomeração, atraídos por um gênero de vida superior, pelas comodidades oriundas da presença de fornecedores, e também pelo atrativo dos espetáculos, do teatro, do anfiteatro, etc... enfim, pelo desêjo de desempenhar funções municipais, onerosas mas muito honoríficas.

A cidade medieval, se percorrermos de um só salto tôda a evolução que nos seria necessário para a descrevermos, apresenta um esquema muito diferente e bem conhecido: ela é individualizada pela muralha que encerra casas estreitamente apertadas umas contra as outras; arrabaldes ultrapassando as muralhas, subúrbios industriais e comerciais que, pouco a pouco, são englobados no perímetro urbano; os mapas nos mostram então tôda uma série sucessiva de muros fortificados. Trata-se, portanto, de formas urbanas que invadem contìnuamente as formas rurais dos arredores, que englobam uma grande parte do campo. Mesmo nas zonas que, materialmente, topogràficamente, não são tocadas pela proliferação monumental que provoca o desenvolvimento urbano, sofrem a influência da cidade, são penetradas pelas influências urbanas. Essa nova cidade é habitada por burgueses que vivem sobretudo do comércio e da produção industrial e formam um patriciado urbano, uma classe rica e dirigente. Ela é habitada, também, por um proletariado urbano - artífices e operários - que permite à cidade desempenhar o seu papel de centro produtor. Se queremos resumir o papel, a função dessa cidade medieval, podemos dizer que ela é, antes de mais nada, uma cidade de função econômica.

Como e por que no nosso Ocidente de velho fundo rural, florestal mesmo, passa-se dessa primeira forma urbana, a da cidade antiga, à segunda, a da cidade medieval? $\mathrm{E}$ quais são as causas e as modalidades dessa decadência urbana, depois dêsse primeiro desenvolvimento? Sobretudo, em que momentos aparecem elas no no Ocidente bárbaro e, enfim, que traçado preciso e que cronologia atribuir à curva da evolução urbana do III ao XI século? Curva, 
nós o sabemos, que desce até um certo momento, a determinar, e em seguida sobe. Qual é o ponto mais baixo da curva, segundo os lugares considerados, e qual é a progressão no espaço dêsse reerguimento urbano que se esparrama como uma mancha de óleo? Esse é o problema de conjunto muito vasto, da evolução urbana durante a Alta Idade Média (e. não os diferentes problemas de história urbana, que são imensos e numerosos) que queremos examinar.

Para tentar traçar com a maior precisão possível a curva da evolução urbana, sua cronologia e sua geografia, será necessário evadirmos do círculo estreito do horizonte ocidental: durante a Alta Idade Média o ritmo do movimento urbano não se desenvolve em compartimento estanque no interior dos paises do Ocidente. Partindo do Ocidente, no III século para voltar até aí no século $\mathrm{XI}$, devemos concluir um longuíssimo périplo, um périplo mediterrâneo e oriental, e então poderemos apreender melhor aquilo que se chamou o renascimento urbano e poderemos precisar meIhor a sua cronologia e os seus itinerários.

Périplo muito longo; sobretudo périplo difícil, em conseqüência das línguas empregadas pelas nossas fontes: latim e grego, mas também árabe, hebraico, siríaco, persa, etc.... Ora, se o medievalista conhece geralmente muito bem o latim e o grego, não conhece, na maioria das vêzes, salvo honrosas exceções, as línguas orientais. E' justamente por essa ignorância lingüística de uma parte da sua documentação que se explica o êrro daqueles que fazem intervir o fatcr "Oriente", "Islão" ou "Maomé" - sem escapar do quadro estreito que ine impunham as fontes ocidentais, e, mais particularmente o êrro de Pirenne. O grande historiador belga traduziu por ruptura na história das relações entre o Oriente e o Ocidente aquilo que não era mais que ruptura nas fontes e nos dados que pôde obter. Um outro êrro aparece na obra de Pirenne (e sobretudo nos seus dois livros de síntese, Mahomet et Charlemagne e Les villes du moyen âge, onde precisou suas teorias gerais): um defeito de perspectiva histórica que lhe fêz adotar uma cronologia muito curta, cerrada demais para as influências que acrecitava pcder divulgar, influências que não podiam ser propagadas tão depressa como o disse, levando-se em conta as condições gerais da econcmia da Alta Idade Média. Para êle, as conquistas "árabes" não tinham ainda terminado e imediatamente, ipso facto, a economia deteve-se no Ocidente e a cidade que aí se teria mantido desde a Antiguidade entra em decadência. Notemos de passagem que êle dispunha de muito pouco tempo para colocar essa famosa queda da curva da evolução da cidade, provocada, segundo êle, pela expansão do Islão, antes de perceber, graças às fontes de que dispunha e que bem conhecia, o início da ascenção; 
daquilo que chama, muito justamente, de renascimento urbano do Ocidente. Essa rapidez, que atribui ao contra-golpe possível das conquistas islâmicas sôbre a economia do Ocidente bárbaro, é necessário explicar pela projeção inconsiderada das teorias da economia contemporânea num passado muito longínquo. Os economistas atuais vivem em nosso mundo moderno e mesmo numa parte do nosso mundo moderno: as economias da Ásia Central, da África Negra ou das ilhas polinésicas não aparecem quase sempre nos tratados de economia política. O assunto dos economistas é antes de mais nada a parte mais evoluida, a mais febril, a mais rápida do nosso planeta, aquela onde um acontecimento de um dia em New York pode ter uma reação imediata nas praças de Londres ou de Paris; é nesse quadro de ações e de reações ultrarápidas, quase instantâneas, permitidas pelos atuais meios de comunicações, que os nossos economistas modernos elaboraram suas teorias e suas leis.

Os historiadores lhes devem muito e não se trata de diminuir aqui a importância da sua contribuição na introdução de novos pontos de vista atualmente aceitos pela ciência histórica. Sòmente é necessário colocar o ponto de partida entre o método e os resultados do trabalho. Esses resultados, válidos para o nosso tempo na maioria dos casos, não devem ser transportados para o. passado e sobretudo para um passado muito afastado de nós como o é a Alta Idade Média, de clima econômico muito diferente, cuja característica principal é justamente a extrema lentidão dos processos, dos ciclos econômicos, das ações e das reações, lentidão devida naturalmente em primeiro lugar à dificuldade das comunicações e à imensidade dos espaços caracterizados ainda por um gênero de vida muito primitivo, por uma economia muito pouco diferenciada. Se atualmente as zonas de economia primitiva nos aparecem como ilhas no meio das ondas da circulação moderna, na época de que nos ocupamos, a Alta Idade Média, essas zonas de vida primitiva se estendiam sôbre a quase totalidade do globo, e, por outro lado, eram ínfimos os pontos onde tinham sido adquiridos uma certa técnica das relações gerais e uma relativa diferenciação econômica. Não eram mais que pequenas ilhas ligadas. umas às outras por laços mantidos no meio de imensos espaços selvagens e quase vazios. E' necessário, pois, tomar em consideração, quando se projeta os problemas econômicos no passado essas conđições materiais tão diferentes das nossas e também os quadros mentais talvez ainda mais diferentes. E' nesse momento que - historiador deve se voltar para a sociologia que o esclarecerá. sôbre essas mentalidades tão estranhas às nossas. Assim se impõe uma colaboração, em todos os instantes, entre o economista "puro", o sociólogo "puro" e o historiador que se poderia, por opo- 
sição, qualificar de "impuro", pois que nele devem se misturar tôdas essas qualidades para "dobrar as teorias às curvas do real", como dizia Bergson.

Dêsses poucos dados gerais pode-se tirar uma regra para o historiador economista que se ocupa (tomemos precisamente a Alta Idade Média como exemplo) de um período muito diferente do nosso: é necessário que êle se mantenha ao corrente dos últimos trabalhos dos economistas e que projete no passado os problemas que êstes estabeleceram para o nosso tempo, os problemas e não os resultados, os métodos e não as teorias já consagradas, e isso tendo em grande conta o momento e o meio social para onde são transportados ou melhor transpostos êsses problemas. Assim é na ligação íntima verificada entre o desenvolvimento urbano e a circulação monetária. Durante a Alta Idade Média, como na época moderna, uma nítida relação existe entre o afluxo de metais preciosos e o aumento do volume das moedas em circulação, de um lado, e, da outra parte, o desenvolvimento urbano, a multiplicação e o crescimento das cidades. De um outro modo, os ritmos monetário e urbano se confundem: tôda restrição na circulação monetária (baixa da exploração mineira, corte das rotas de introdução de ouro novo, fuga externa causada por uma balança de comércio deficitária, entesouramento) se traduz pela decadência urbana, uma baixa da atividade econômica das cidades e uma perda de sua potência social; pelo contrário, todo novo afluxo de metais monetários (descoberta de jazidas, captura de correntes comerciais que trazem os produtos de minas novas, afluxo de moeda causada por uma balança de comércio favorável, colocação em circulação de ouro entesourado) se traduz por um desenvolvimento urbano muito acentuado, um reinício da atividade econômica e da potência social da cidade, em detrimento do campo e do domínio senhorial. Verdadeiro problema de vasos comunicantes: quando a circulação monetária se faz mais intensa, se apagam progressivamente as formas rurais e o poderio social do campo; ao contrário, essas fôrças rurais dominam quando se trata do fenômeno inverso, como se uma economia monetária recobrisse necessàriamente uma economia urbana.

Essa correlação entre a circulação monetária e o desenvolvimento urbano vai nos permitir melhor precisar as fases cronológicas, a extensão geográfica e as modalidadeş da evolução urbana durante a Alta Idade Média, ou, pelo menớ, estabelecer melhor o problema de conjunto. 
PRIMEIRA FASE: III e IV SECULOS.

1). - Decadência urbana no Ocidente romano.

2). - Desenvolvimento urbano na parte oriental do Império.

André Piganiol, que resume suas idéias num volume da coleção Glotz (2), nos fala da ruína das cidades do III e do IV séculos e nos diz que essas cidades foram arruinadas pelas invasões bárbaras e pelas exações governamentais. No Ocidente, essas invasões se tornaram possíveis pela luta dos exércitos rivais do Reno e do Danúbio, que abandonaram os postos do limes e refluiram para a Itália para melhor lutar e fazer triunfar seus candidatos ao Império. Os bárbaros puderam então lançar grandes incursões através do mundo romano do Ocidente: assim os francos invadiram a Gália e a Espanha, de 253 a 268, os alamanos a Gália e a Itália, em 268, os suábios o Norte da Itália, em 270271. Depois deu-se a terrível invasão da Gália pelos germanos, em 275. O imperador Probo teve que retomar setenta cidades antes de poder repelir os bárbaros para além-Reno. Os ataques combinados se multiplicam, de alamanos, de vândalos, de burgúndios, em 286, em 288 e 291. As cidades são esmagadas: pilhagens, desgastes consideráveis; as cidadels são tomadas, saqueadas, queimadas, etc. ... Como diz um autor da época "as hordas bárbaras transportaram para a Germânia as tiquezas da Gália". Segue-se uma série de movimentos de banditismo, de levante de camponeses, durante todo o IV século. E' a ruína das cidades: "no meio dos entulhos das grandes cidades, grupos esparsos de miseráveis habitações, testemunhos das calamidades passadas; nós só conservamos os nomes de outrora" (3).

O Oriente é também atacaro por povos iranianos, os sármatas, os caucásios, os alanos, e sobretudo pelos germanos orientais, os gôdos: Estes, em 256, avançam até Tessalônica. Do Mar Negro, os navios gôdos e sármatas se lançam através do Helesponto: quase tôdas as cidades da costa da Ásia Menor são destruídas. Em 269, uma verdadeira coalisão de todos os bárbaros das estepes transpõem o Danúbio. São derrotados com grande dificuldade por Cláudio II em Naissos, na Alta Sérvia.

As cidades, para resistir aos bárbaros e aos bandidos que continuavam as pilhagens dos bárbaros, se rodeiam de muralhas, nos séculos III e IV. Na Gália, elas ise rodeiam de muralhas muito apertadas e essas muralhas, fato interessante, procuram muitas vêzes o traçado do velho oppidum gaulês. A cidade, aquilo

(2). - Histoire romaine, IV, 2, L'Empire chrétien (325-395), Paris, 1947.

(3). - Paulo Orósio, Adversus 'Padanos, VII, 22. 
que continua chamar-se cidade, toma então o aspecto de fortaleza, tão característico das cidades medievais, a forma do castrum, do burgus.

O que arruinou as cidade é pois, inicialmente, a pilhagem dos invasores bárbaros. São também, nos diz André Piganiol, as exações governamentais, a política dos imperadores para com as cidades, privando-as de suas riquezas, suprimindo os lucros que elas tiravam das terras que a circundavam e recuperando essas terras em proveito do grande domínio imperial. Por outro lado, as magistraturas não são agora mais que munera. Aos ricos, impõe-se serviços gratuitos e aos pobres pede-se simplesmente a fôrça de seus braços. Uns e outros, para escapar a essas cargas cada vez mais pesadas, fogem da cidade. $O$ rico dirige-se para o seu. domínio rural e o pobre se refugia também no campo, ambos abandonaram a cidade onde são mais fàcilmente submetidos à inquisição do Estado. A população urbana se empobrece, a cidade é progressivamente privada do seu material humano, do seu impulso social. Se as invasões bárbaras demoliram materialmente as cidades, a política dos imperadores as demoliu socialmente. Dêsse fato decorre a decadência urbana, o grande domínio toma cada. vez maior lugar, a ruralização é geral.

Essa análise é muito justa. Sòmente nada indica que ela remonta à primeira explicação, nem sobretudo se ela levou em conta o desenvolvimento urbano muito real na parte oriental do Império. E' entre 324 e 331 que se deu a criação de Constantinopla (4), que será uma das maiores cidades da Idade Média, - durante 'um certo tempo a maior - não perdendo o primeiro lugar senão para Bagdá a partir do século IX. Fato imenso para a história urbana geral e que não se ajusta a essa idéia um pouco simples de uma decadência urbana generalizada a partir do III século.

A causa profunda da decadência urbana do Ocidente romano de um lado e o impulso urbano do Oriente romano do outro, deve ser procurada alhures, na desigual repartição dos estoques de ouro entre o Oriente e o Ocidente. A atividade econômica que declina no Ocidente, mas que se mantêm, mostra essa mudança das condições monetárias e urbanas entre as duas bacias do mundo mediterrâneo nos séculos III e IV. O artigo de G. I. Bratianu sôbre a repartição do ouro no fim do Império romano (5), põe em foco essa diferença de volume dos estoques de metal amarelo nas duas metades do mundo romano. O Ocidente se esvazia cada vez mais do ouro que as conquistas romanas tinham aí acumulado, no mo-

\footnotetext{
(4). - E. Emereau, "Note sur les origines et la formation de Constantinople" (Revue Archéologique, 1925); R. Mayer, "Bizantion, Konstantinopolis, Istambul, eine genetische Stadtgeographie" (Deutscho Akad. Wiss. Wien, Phit.-Hist. Classe, LXXI, 1943).

(5). - In Etudes byzantines d'histoire économique et saciale. Paris, 1938.
} 
mento da pilhagem sistemática dos tesouros amontoados no Oriente helenístico. Esse ouro, a partir do II século e sobretudo durante o II e o IV, foge para o Oriente para pagar a compra de produtos orientais de luxo, tornados essenciais à civilização mediterrânea. O comércio dessas ricas mercadorias orientais estava inteiramente nas mãos dos levantinos: gregos, egípcios e sobretudo sírios. As cidades do Egito e da Síria são os centros de intercâmbio entre os países fornecedores dos objetos de luxo (isto é, o Oceano "Indico e a Ásia, duma maneira geral) e os grandes centros de consumo que são ainda, antes do IV século, Roma e as cidades do Ocidente. E' o momento, a partir do III século, em que os levantinos irão inaugurar seu papel de senhores do comércio do Ocidente. Até o III século, sua atividade se dirigiu sobretudo para o Oriente. Percorrem e dominam as rotas do Mar Vermelho, da Mesopotâmia e do Irã. O Império parta é explorado por êles e o Oceano Indico sulcado pelos navios de Alexandria. Ora, durante o III século, no Oriente, se organizou o Império dcs persas sassânidas que substituiu o Império dos partas arsácidas. A uma organização que se pode chamar filo-helênica, que deixava os estrangeiros da Pars Orientis do Império penetrar no seu território e aí comerciar frutuosamente, sucede um Estado xenófobo, de base estreitamente nacionalista, e os homens de negócios levantinos, durante o III século, não pouco a pouco expulsos das rotas do Oriente. Eles se voltam então para o Ocidente e é êsse o momento em que o comércio ocidental começa a passar para dominação dêsses levantinos, os Syri da Alta Idade Média. Esse é também o momento em que se inicia, por iniciativa dêles, a drenagem do ouro ocidental que terminará pelo esgotamento quase total das reservas no fim do VI e no início do VII século (6). O ouro foge do Ocidente romano, êsse ouro que é o motor de uma vida econômica ativa e a base de uma vida urbana próspera. Pelo contrário, a circulação do ouro na parte oriental do Império, nos III, IV e V séculos, permaneceu ativa. E' ela que permitirá às velhas metrópoles helenísticas, Alexandria e Antioquia, continuar sua atividade econômica e que permitirá também a criação e depois o desenvolvimento da nova grande cidade, Constantinopla. Essa criação constantiniana deve ser ligada à um outro fato que é também a obra de Constantino: a cunhagem de uma moeda sólida, o solidus aureus, que é chamado, nas províncias orientais, o denarios chrusos ou o denário de ouro, designação que é a origem do vocábulo árabe dinâr, a grande unidade monetária do Califado.

(6). - Para a evolução dos problemas monetários durante a Alta Idade Média, indicamos, uma vez por tôdas, Marc Bloch, "Le problème de l'or au moyer âge" (Annales d'histoire économique et sociale, $V, 1933$ ) e o nosso artigo, "L'or musulman du VIIe au XIe siècle" (Annales. Economies. Sociétés. Civilisations, II, n. ${ }^{\circ}$, pp. 141-160 e Revista de História, n.0 13, pp. 25-46, 1953 ). 
a

O movimento urbano é atraído no Oriente por essa circulação monetária que permanece intensa, enquanto que no Ocidente, êle se detêm e decresce: anemia urbana que não é mais que o corolário da anemia monetária.

$$
*
$$

SEGUNDA FASE: V-VII SECULOS.

1). - Decadência urbana acentuada no Ocidente bárbaro.

2). - Estagnação, depois recuo do movimento urbano no Império bizantino.

3). - Desenvolvimento urbano no Oriente sassânida.

Novos invasores se precipitam sôbre o Ocidente, acabando de arruinar as cidades da Pars Occidentalis, já submetidas a rudes provações no III e no IV séculos e que, na sua maioria, não tinham podido reerguer-se de suas ruínas: conhecemos as dificuldades da reconstrução em período de depressão econômica, a impossibilidade dessa reconstrução quando falta o dinheiro. As cidades - ou aquilo que delas resta - são de novo taladas e pithadas pelas grandes invasões do $\mathrm{V}$ século, principalmente as cidades da Gália, em 406-407. Um autor nos diz que tôda a Gália se queimou como uma tocha: "Uno fumavit Gallia tota rogo". As cidades da Espanha e da África do Norte são devastadas pelos vândalos. As cidades da Itália pelos hunos, os visigodos e os vândalos: em 451, Aquiléia é completamente destruída e, no século seguinte, não se reconhecia mais o local dessa poderosa cidade, durante muito tempo o principal centro de comércio da Itália do Norte e a grande provedora do limes danubiano. Os habitantes de Aquiléia fugiram para todos os lados; muitos foram se refugiar nas lagunas do delta do Pó e de seus afluentes. Lá êles se instalaram num local um pouco mais elevado, dominando as terras baixas, rivum altum, Rialto, a futura Veneza. Mas Veneza não toma logo de início impulso; seu magnífico desenvolvimento urbano é devido a uma outra causa, ao momento em que a moeda afluirá para essa região do fundo do Adriático, permitindo a Veneza desempenhar um papel de árbitro entre o mundo ocidental, de estalão monetário de prata, e o mundo oriental, bizantino ou muçulmano, de estalão monetário de ouro. No momento, sòmente algumas cabanas de pescadores marcam o território onde se erguerá uma das primeiras cidades do Ocidente a ser atingida pelo movimento renovador. Os dois saques de Roma (em 410, pelos visigodos de Ala- 
ríco, e em 455, pelos vândalos de Genserico) completam a lista das ruínas novas acrescentadas às antigas.

Mas ao lado dessas ruínas e as tornando irreparáveis é necessário também e, sobretudo, notar a acentuação da fuga do ouro do Ocidente para o Oriente. Se a moeda tivesse podido afluir para essa região do mundo espezinhada pelos bárbaros, as tarefas da reconstrução teriam sido grandemente facilitadas e as cidades destruídas, após o primeiro momento brutal da conquista, teriam podido se reerguer das suas ruínas. Mas o volume de ouro em circulação se atenua cada vez mais nos reinos germânicos: êle diminuiu, inicialmente após um entesouramento maciço que se produziu na época das invasões: foram encontrados muitos tesouros enterrados nas vizinhanças das muralhas, marcando o perímetro urbano dos castra e dos burgi. Esse ouro ficou inteiramente perdido para a circulação monetária da época. Quanto ao ouro não entesourado, êle foi empregado para comprar nos países do Oriente algumas migalhas de um luxo que a decadência das técnicas não permitia mais ao Ocidente produzir êle próprio e os bárbaros eram apaixonados pelos belos trajes e ricas jóias. Esse comércio de importação, se nos colocarmos no Ocidente, é cada vez mais monopólio dos Syri. E' um comércio num único sentido, sem compensação de mercadorias, o Ocidente não tinha então nada para exportar para o Oriente, nada que o Oriente não pudesse produzir in-loco, no Egito, na Síria, nos países do Mar Negro ou nos Balcãs.

E' necessário insistir um pouco sôbre êsse aspecto do comércio ocidental. $\mathrm{O}$ grande comércio das regiōes do Ocidente, na bela época romana, era essencialmente um comércio de exportação de víveres e de matérias primas, com destino sobretudo ao grande mercado de consumo que era Roma (que contava cêrca de um milhão de habitantes, o que representava um enorme centro de atração). Tratava-se, pois, daquilo que chamamos um comércio de matérias ponderosas. Esse comércio vai desaparecer com o declínio do mercado urbano de Roma, com o abandôno de Roma por Constantinopla. Uma prova disso, entre outras, está nas margens do Tibre: o monte Testaccio, que não é mais do que uma colina eregida com os restos das ânforas que serviram para conter o azeite da Espanha trazido para o consumo da capital: essas ânforas são datadas e a última data encontrada nos seus cacos é de 257 (7). Pelo contrário, o comércio oriental de luxo, êsse vai sobreviver. E' um comércio de objetos muito leves e ao mesmo tempo muito valiosos que rendia muito por um pequeno volume de mercadorias; êsse comércio vai se manter, pelo menos enquanto durar no Ocidente a possibilidade (e não sòmente o desêjo) de comprar ricos trajes e brilhantes enfeites oferecidos pela in- 
dústria oriental; isto é, enquanto subsistir no Ocidente uma classe de ricos possuindo ouro: os soberanos, os grãos senhores ou as igrejas. São êles que fazem ofertas aos produtos de luxo do Oriente trazidos pelos Syri. Esse comércio vai se amenizando, ao mesmo tempo que ainda continua pelo menos até os fins do VI século. Nesse momento houve uma parada completa das correntes comerciais no Ocidente bárbaro. Os Syri não vêm mais ao Ocidente porque o Ocidente não podia mais thes fornecer as moedas de ouro a que estavam acostumados a vir buscar antes. Verificamos então uma verdadeira atonia monetária que se traduz pelo aspecto miserável das moedas, pela circulação reduzida ao extremo e pela suspensão das relações em geral. E' nesse momento que podemos colocar a parte mais baixa da curva econômica e o ponto mais baixo atingido pela decadência urbana: fim do VI ao comêço do VIII século. $\mathrm{O}$ aspecto rural, dominial, prevalece cada vez mais em tôdas as regiões do Ocidente: na Inglaterra, na Gália, na Espanha e na Itália. O velho fundo rural que é o do Ocidente, mesmo o velho fundo florestal que é o da parte nórdica do Ocidente, reaparece calda vez mais.

Na África do Norte, não é o domínio rural quem ganha, mas a tenda, o nomadismo; o velho fundo estépico, tornando ao deserto, reaparece e se torna invasor. O nômade africano sôbre seu cavalo barbe (berbere) foi repelido ou fixado pelo desenvolvimento urbano, trazido inicialmente por Cartago, e em seguida sobretudo, por Roma; mas o nomadismo vai reaparecer e aumentar seus territórios de pastoreio a partir do III século, ocasião em que dispõe dum novo e possante instrumento, o camelo, que acaba de ser introduzido na Berbéria pela Cirenaica (8). A criação do dromedário se desenvolve e, com êle, a tribo cameleira. Zonas cada vez mais importantes foram ganhas pela vida pastoral, tiradas às culturas criadas para a alimentação das massas urbanas; a grande luta começa entre o nômade e o sedentário, entre o cameleiro e o cultivador; conflito que ainda dura, mas que termina em nossos dias em detrimento do nômade cameleiro. A cidade, na África do Norte, não foi devorada pelo campo. Ela morreu porque não titha mais campos ao seu redor, porque as terras de cultura voltaram ao pastoreio, à estepe, às áreas do nômade. As cidades africanas, tão vivas na época romana, se contraem, se despovoam em face dos nômades, exatamente como elas o fazem, na Europa ocidental, em face dos grandes domínios rurais.

Ruralização de um lado, nomadização do outro, decadência urbana e barbarização dos dois lados. Por que essa deflação urbana? Por que a cidade não tem mais, para se defender, sua arma

(8). - St. Gsell, in Mémoires de l'Academie des Inscriptions et Belles Lettres, XLIIr, 1926. 
própria, a moeda. Mais tarde, sem que as condições naturais tenham mudado, quando a moeda voltar, quando a região fôr de novo irrigada pelo medium das trocas a vida urbana renascerá, na Europa ruralizada como na Âfrica nomadizada.

Se passarmos agora para a bacia oriental do Mediterrâneo, veremos inicialmente a suspensão do grande movimento urbano marcado pela criação e pelos primeiros progressos de Constantinopla, depois uma estagnação e, em seguida, um recuo da atividade urbana no Império bizantino: o desenvolvimento urbano se retardou na segunda parte do VI século, depois se deteve no início do VII. Então se produziu uma contração e uma compressão da atividade urbana e, paralelamente, uma evolução para o grande domínio, para a ancilose dominial. O poderio do grande domínio se acentuou cada vez mais na medida que a influência da cidade se atenuou. Sôbre o plano social a senhoria territorial apareceu, a grande mansão senhorial estava em vias de se cristalizar. Sôbre o plano econômico, a célula dominial fechada estava em formação. No VII século, no Oriente mediterrâneo, não chegamos ainda à forma quase perfeita que a senhoria revestia nesse momento no Ocidente bárbaro, mas para isso nos encaminhamos. Podemos seguir as fases dessa transformação nos papiros egípcios, massa de documentos emanados na sua maioria dos escritórios dos grandes proprietários (9). Um outro testemunho nos permite também compreender essa evolução para o conjunto dos territórios bizantinos: os rescriptos imperiais mostram a luta incessante levada a efeito pelos imperadores contra as usurpações das grandes aristocracias territoriais, e os esforços paralelos que êles fazem para dar uma nova vida às cidades. No Oriente bizantino, que conservou suas formas estatais, com sua economia dirigida pelos escritórios centrais, cs kasilieis se esforçaram para freiar, com o's mais variados sucessos, a evolução natural rumo à forma dominial. Eles não podiam impedir o declínio do movimento urbano. As cidades do Delta egípcio, outrora tão ricas e tão povoadas, se empobreceram em moedas e em homens. As burguesias das cidades do interior, mais ràpidamente atingidas, afluiram para Alexandria que permaneceu como um centro econômico ainda ativo e que, cada vez mais, apareceu como um mundo a parte, justaposto à terra egípcia que, ela, retornou pouco a pouco às suas formas rurais primitivas. 0 mesmo aconteceu no interior do país: não demorou que a massa dos camponeses indígenas (os coptas, os felás), os padres, os monges - que se apossaram de tôdas as terras em tôrno dos seus mos-

(9). - E. Rochie Hardy, The large estates of Byzantine Egypt, New York, 1931; H. I. Bell, "An epoch in the agrarian history of Egypt" (Recueil d'études égyptologiques, dedicados à memória de Champollion). 
teiro fortificados (10) - e também os grandes proprietários territoriais que viviam em seu domínio com os seus oficiais, seus guardas e seus servidores; em resumo, o servo e o seu senhor, ainda que êsse senhor seja laico ou eclesiástico.

As crônicas siríacas mostram o mesmo espetáculo: na Síria, como no Egito, a atividade ainda se manteve nas cidades comerciantes da costa, mas, no interior, não existiam mais cidades verdadeiramente importantes; não se encontravam mais que populações rurais submetidas aos grandes proprietários territoriais e entre os quais começavam se infiltrar os árabes nômades (11).

Temos a mesma evolução na Ásia Menor, onde as cidades do planalto anatólico declinaram, enquanto que alguns portos permaneceram bastante ativos no Mar Egeu. No interior, se edificaram as grandes mansões senhoriais, cuja independência e turbulência vão em seguida perturbar tão profundamente o Império bizantino. Aí se desenvolveram também as formas de nomadização: extensão de zonas de pastoreio e multiplicação de grandes rebanhos de carneiros, tôda uma vida pastoril que se estendeu ao mesmo tempo que desapareceu $o$ aspecto urbano tão característico da Ásia Menor na época do início do Cristianismo e dos primeiros concílios.

A mesma coisa se passou na península dos Balcãs, onde tôda a atividade econômica e urbana se concentrava em Constantinopla e em Tessalônica; o resto da região se submeteu a uma ruralização muito nítida, ainda acentuada pela instalação dos eslavos, desde o VI século, na Macedônia, na Grécia central e no Peloponeso. Estes trouxeram consigo formas particulares de ocupação do solo: aldeia dispersa, com pequenas casas separadas por culturas, a $Z a-$ drouǵa eslava que não tinha mais nem o aspecto, nem a função de cidade, no sentido em que nós o entendemos: um núcleo monumental com valor econômico.

As cidades, no Oriente bizantino do fim do VI e do início do VII séculos pareciam, pois, com ilhotas no meio duma economia agrícola e pastoril que aumentava sem cessar. O recuo urbano era muito nítido, a ancilose dominial aumentava e os ganhos do nomadismo eram importantes, apesar da luta desesperada dos imperadores para sustentar o movimento urbano, para lutar contra as grandes casas senhoriais e manter em respeito as hordas nômades. Eis aí o grande acontecimento da história urbana bizantina do VI e do VII séculos. A razão profunda deve ser procurada numa restrição da circulação monetária. E' o momento em que as rotas que traziam às oficinas bizantinas o ouro do Ural e da

(10́). - U. Monneret de Villard, "Descrizione generale del monasterio di San Simeone presso Aswan" (Annales du Service des Antiquités égyptiennes, XXVI, 1926). (11). - R. Dussaud, Les Arabes en Syrie avant I'Islam, Paris, 1907. 
Núbia foram cortadas pelos incursões dos nômades; o momento em que diminuiu a torrente de ouro que vinha do Ocidente por intermédio dos Syri, o momento em que se acentuou a fuga do ouro: no interior do Império pelo entesouramento, fora das fronteiras em direção a Leste, rumo ao Império sassânida que era então o ponto obrigatório de passagem dominando tôdas as rotas do comércio entre o Oceano Indico e o Mediterrâneo. Os dois processos se completavam: decadência urbana e, ao mesmo tempo, diminuição do volume de ouro em circulação.

$$
* * *
$$

Continuemos mais longe para Leste e passemos agora, para - Império sassânida. O Irã, como a Mesopotâmia, é composto de regiões sêcas, de zonas de desertos pontilhados de oásis que se sucedem como contas dum rosário desde a Ásia central até ao $\mathbf{M e -}$ diterrâneo e o Gôlfo Pérsico. Nesses oásis se desenvolveu uma vida particular, ligada inteiramente à irrigação que permitiu o cultivo em grande escala de árvores frutíferas, de palmeiras e também de plantas de caráter tropical: o arroz, a cana de açúcar, o algodão. Essas culturas irrigadas, ajardinadas, são culturas intensivas e elas proporcionam imensas possibilidades para a alimentação e vestuário de grandes aglomerações urbanas. Pode-se dizer que o oásis atrai e sustenta a cidade. Enquanto que a floresta ocidental era hostil à cidade, tanto que grandes clareiras cultivadas não a arejaram nem a enriqueceram, o oásis oriental era favorável ao desenvolvimento de grandes metrópoles. No vasto oásis que é a Mesopotâmia, sucederam-se populosas capitais do Oriente: Babilônia, depois Selêucia, após Ctesifonte. A cada impulso urbano correspondeu uma extensão de terras cultivadas.

A época sašânida se caracterizou por um imenso desenvolvimento da irrigação das plantações e, ao mesmo tempo, por um movimento urbano em plena expansão. Isso é um fato capital que ainda não foi bem acentuado. Numerosas cidades foram criadas pelos soberanos sassânidas, que tôdas nossas fontes apresentam como grandes construtores, e encontramos mesmo na toponímia iraniana, seus nomes seguidos da terminação abad, "a cidade" (Firouzabad, Bahramabad...) ou incorporados ao nome da nova cidade (Rêv-Ardachîr, Nêv-Châhpouhr, Râm-Kavâdh...). Em tôrno do duplo núcleo antigo de Selêucia-Ctesifonte se ergueram do IV ao VII séculos, aglomerações satélites (Vêh-Ardachîr, Mhhôzê....) donde se originou o nome de Madâin, "as cidades" dado a êsse conjunto pelos autores árabes (12). Essas cidades sassâ-

(12). - Cf. os relatórios das expedições alemãs ao local de Ctesifonte: $O$. Reuther, Die deutsche Ktesiphon-Expedition 1928-1929, Berlim, 1930; E. Kühnel e $O$. Wachsmuth, Die Ktesiphon-Expedition, 1931-1932 (Berlim, 1933); J. H. Schmidt, "L'expédition de Ctésiphon en 1931-1932" (Syria, XV, 1934). 
nidas eram habitadas por uma população de artífices, de comerciantes, por uma "burguesia" enriquecida no comércio, população que não era nobre, mas que era livre, que pagava uma taxa pessoal ao Estado, mas que não estava obrigada nem às corvéias, nem ao serviço militar (13). E' o momento em que, às tradicionais classes do Avesta: Fadres, guerreiros e agricultores, vêm juntar-se uma quarta classe, a dos Hoûtoukhch ("os industriosos" em pehlvi) que compreendia ao mesmo tempo os artífices e os comerciantes (14). Essa classe ativa da população não se criou então, mas a consagração que ela obteve no quadro religioso indica nìtidamente o aumento do seu poderio econômico e social. No VI século, o vasto e profundo movimento social do Mazdakismo, colorido, como sempre no Oriente de Messianismo religioso, tornou bastante patente a importância cada vez maior tomada pelas massas urbanas no Império sassânida. Paralelamente, verificou-se o decínio progressivo dos senhores territoriais, os dihqâns ("os nobres proprietários de terras"). Eles perderam cada vez mais sua influência social e a sua riqueza econômica e, no Irã, como na Mesopotâmia, iniciou-se uma verdadeira crise nobiliária, crise da fortuna dos nobres, da fortuna de proprietários territoriais, em face da nova fôrça que subiu, a dos burgueses, de fortuna mobiliária.

No Império sassânida, o sentido da evolução era assim muito diferente daquilo que pudemos verificar no Império bizantino e no Ocidente bárbaro. A nota dominante aí era dada pela expansão das cidades e o recuo dos grandes proprietários territoriais: estamos aqui num domínio de larga circulação monetária. Não era a moeda de ouro que circulava, mas a moeda de prata. O ouro estava entesourado sob a forma de lingotes, de jóias ou de objetos preciosos e o que circulava de maneira intensa, era o drama sassânida, o direm. Essas peças de prata foram cunhadas em enormes quantidades por numerosas. oficinas esparramadas por todo 0 Império. Nas escavações de Susa, J. de Morgan encontrou uma grande quantidade de dracmas de Cosroes II (590-628), com índices monetários os mais variados, representando a maioria das grandes cidades do Império sassânida (15): prova duma muito ativa circulação monetária e de um grande desenvolvimento do comércio no Oriente sassânida, no início do VII século, nas vésperas da conquista muçulmana. E' o momento em que o direm persa de prata difundiu-se não sòmente no interior do grande Império sassânida, mas também muito longe em direção ao Sudeste e Noroeste (Oceano Indico e estepes Ponto-caspianas) onde conquistou as posições precedentemente ocupadas pelo nomisma bizantino.

\footnotetext{
(13). - A. Christensen, L'Iran sous les Sassanides, Copenhague-Paris, 1936.

(14): - E. Benveniste, "Les classes sociales dans la tradition avestique" (Journal Asiatique, 1932).

(15). Manuel de numismatique orientale, Paris, 1936.
} 
Do $\mathrm{V}$ ao VII séculos pode-se, pois, verificar uma espécie de recuo monetário do Ocidente em face do Oriente e essa evolução monetária estava estreitamente ligada ao próprio ritmo da atividade urbana. No Ocidente bárbaro, as formas urbanas desaparecem; o grande domínio triunfa na Europa e o nomadismo na África do Norte; a circulação monetária desapareceu quase completamente no fim dêsse período. No Império bizantino, a atividade urbana se contraiu, a ancilose dominial e a vida pastoril aumentaram no Egito, na Síria, na Ásia Menor e nos Balcãs, o fluxo. monetário diminuiu e se condensou cada vez mais. No Oriente sassânida, o ritmo urbano se acelerou, o poderio dos senhores territoriais diminuiu, a circulação do direm se tornou cada vez mais intensa e sua área vitoriosa se estendeu por todo o Médio Oriente, da India ao Mar Negro.

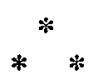

TERCEIRA FASE: VII-XI SÉCULOS.

1). - Expansão urbana no mundo muçulmano.

2). - Início da renovação urbana no Ocidente.

3). - Desenvolvimento urbano de Bizâncio.

Se nos colocarmos no interior mesmo do mundo muçulmano: uma vez formado, verificaremos por tôda a parte uma prodigiosa expansão urbana, e lá onde ela estava em curso, a suspensão do processo dominial que indicamos mais acima e que os papiros egípcios nos permitem seguir com algumas minúcias. O testemunho. dêsses papiros, nós continuamos a possuí-los para os primeiros séculos do período muçulmano; êle nos é precioso para prosseguir no traçado da curva. Vamos aqui mudar de aspecto e de rumo.

Nas vésperas da conquista muçulmana, o domínio senhorial estava no Egito em vias de se organizar econômicamente e socialmente, assim como o senhor e seus servos. Encontramos nos papiros de Afrodito, antes da conquista, fórmulas dêste gênero:

"o miserável servo Anoup (Anubis) se prosterna diante do muito magnífico patricio, êle se roja sôbre o rastro dos passos imaculados do poderoso duque Atanásio".

Logo após a conquista, essa evolução se deteve. Houve o esmigalhamento da célula dominial que estava em vias de comple-- 
tar sua formação e, desde então, o servo e o senhor, o muito magnífico Atanásio e seu miserável escravo Anoup foram colocados em face do novo Estado muçulmano numa posição quase idêntica. Todos os dois pagaram a capitação e o impôsto territorial, a que eram obrigados todos os não-muçulmanos. $O$ produto do tributo assim recebido era repartido entre os membros da comunidade muçulmana. Estes viviam nas cidades, não cultivavam a terra, eram verdadeiros arrendadores do solo, recebendo as rendas pagas pelos habitantes dos campos. Assim, o regime dominial que se consolidava durante $\circ$ período precedente, desassociou-se e transformou-se.

Essa derrota do sistema dominial era ainda acentuada pela importância cada vez maior assumida pela moeda, pela fortuna mobiliária. Como para muitas das nossas grandes cidades contemporâneas, o crescimento rápido das metrópoles muçulmanas era em grande parte provocado pela inflação - aqui metálica - e pela alta dos preços que the era consecutiva. O brusco enriquecimento da classe mercadora das cidades lhe permitiu investir seus ganhos na compra de propriedades no campo. O proprietário recebeu o lucro de suas terras, mas permaneceu na cidade; êle também era um arrendador do solo. Assim, cada vez mais, econômicamente e socialmente, a cidade dominava o campo circunviziriho, o citadino impôs sua direção ao rural. Um ativo intercâmbio ligou de novo estreitamente o campo e o mercado urbano em plena expansão: solicitação de produtos do solo para o reabastecimento da cidade; convocação da mão-de-obra rural para as oficinas urbanas. A época capital para uma cidade era, com efeito, o momento em que ela se criou; a sua construção, no ponto de vista econômico e social, era um enorme centro de atração que fazia sentir ao longe a sua influência incitadora. O velho adágio "Quando a construção vai bem, tudo também vai", era inteiramente aplicável a essa construção urbana que agrupava milhares e milhares de obreiros, reunidos depressa e de tôda parte para a ereção rápida da nova cidade. Dêsse movimento de população do campo para a cidade em construção - mão-de-obra rural arrebanhada pela cidade - conhecemos numerosos exemplos, nas longas listas fornecidas pelos papiros egípcios, de camponeses requisitados nas aldeias do vale do Nilo para as oficinas urbanas: eram enviados a trabalhar em Foustât (antigo nome do Cairo), para construir os edifícios públicos e o palácio do governador; mais longe ainda: para Damasco, para participar da construção da Grande Mesquista dos Omíadas; para Tunes, para construir aí os muros e os barcos do novo arsenal marítimo. Para fornecer a mão-de-obra aos arsenais sírios, populações inteiras são transportadas das margens do Gôlfo Pérsico e do Mar Vermelho para os portos mediterrâneos. 
Notemos a êsse propósito que se pode aproximar dessa migração de população marítima, a passagem da vela chamada "latina", do domínio do Oreano Índico para o do Mediterrâneo durante o VIII século.

Assim se operou uma mistura de populações, de progressos técnicos, de quadros mentais, essencialmente contrários ao acabamento da célula dominial fechada, que tínhamos descrito, segundo os papiros egípcios, em via de formação já avançada nas vésperas da conquista muçulmana. Trocas sempre mais estreitas entre a cidade e o campo mudaram o sentido da evolução; a célula dominial se desagregou sob o choque dum intenso apêlo partido dos centros urbanos em expansão.

Essa expansão urbana, êsse prodigioso desenvolvimento das cidades, da economia e da civilização que elas representam, nos aparece como a característica essencial do mundo muçulmano entre o VII e o XI séculos. Esse "período muçulmano" é um dos granđes momentos da história geral do movimento urbano. Os outros grandes perícdos urbanos foram grandemente estudados, mas não o período muçulmano. A tentativa de síntese de Georges Chabot, Las Villes (na pequena coleção Armand Colin), enumera "os grandes períodos urbanos": época helenística, Império romano, Ocidente do XII século, XIX século.' Mas êle omitiu, entre o Império romano e o século XII, a admirável expansão urbana que o munđo muçulmano conheceu do VII e ao XI século, expansão quis, em cutros lugares, como veremos, é a origem da renovação das formas urbanas do Ocidente cristão nos séculos XI e XII.

E' para precisar alguns aspectos dêsse fato capital - e tão pouco valorizado - que nos ocuparemos agora.

Em primeiro lugar, qual era sentido de propagação do movimento urbano através do imenso domínio econômico recém-construído pelas conquistas muçulmanas? Êle se dirigiu de Leste para Oeste: êle se ampliou no antigo Império sassânida (Irã, Mesopotâmia), já em período de expansão antes da conquista muçulmana; começou de novo nas antigas províncias bizantinas (Síria, Egito), onde estava retardado; renasceu nas regiões do Ocidente mu. çulmano (África, Espanha, Sicília), onde tinha desaparecido havia muito tempo. Esse intenso desenvolvimento urbano no mundo muçulmano revestiu-se de duas formas: primeiramente o desenvolvimento de antigos centros que retomaram uma vida nova e se dilataram topogràficamente e demogràficamente, econômicamente e socialmente (Damasco, Córdoba, Palermo), em segundo lugar a criação ex-nihilo de cidades novas (Cairoão, Badgá, Fez).

No antigo Império sassânida se ergueram sucessivamente: Cufa, sôbre o Eufrates e Báçora, o grande pôrto, no fundo do Gôlfo Pérsico (637-638); Wâsit (695) e scbretudo Bagdá, a gran'de ci- 
đade abácida, sôbre o Tigre (762-766). Désde o IX século, menos de cem anos após a sua criação, Bagdá já era a maior cidade do mundo. Em 836, uma nova cidade-residência califal se ergueu sôbre o Tigre, a três dias de marcha acima de Bagdá: Samarra, a Versalhes abácida, que se tornou muito depressa um importante centro econômico. O comércio muçulmano do Oceano Índico partindo de Báçora, pelas suas feitorias da costa oriental da África, introduziu as formas urbanas nessa parte do continente negro. Mogadíscio, Barawa, Kilwa, Melinda, Mombaça foram criadas; cidades onde chegavam do interior as filas de carregadores negros com seu carregamento de ouro e de marfim e de onde partiam as correntes de islamização para o coração da África (16).

No antigo Império bizantino por tôda a parte se notava um reinicio de atividade urbana; cidades se desenvolviam, cidades que quase tinham desaparecido na época precedente (Damasco, Alepo), numerosas pequenas cidades brotavam na Síria e no Egito. A história urbana no vale do Nilo foi dominada pelo enorme desenvolvimento do antigo centro de Babilônia do Egito, na ponta 'do Delta, que proliferou projetando em tôrno de si uma série de cidades populosas: Foustât (VII século), Al-'Askar (VIII século), Al-Qata'i, a tulunida (IX século), Al-Kahîra (o Cairo), a fatímida (IX século).

No Mediterrâneo ocidental se criaram as cidades de Cairoão (670), Tunes (698), Tahert (761), Fez (807), Tenés (875), Orão (903), al-Mahdîya (915), Argel (946), Qala'a dos Beni-Hammad (1007), Marráquexe (1077). Em tôrno de Cairoão pulularam palácios principescos, núcleos de cidades desde logo bastante povcadas e conômicamente desenvolvidas: al-Abbâssiya, onde o emir aglábida recebeu, em 801, os enviados de Carlos Magno, arRaqqâda, criação do aglábida Ibraim II (876), Sabra-Mansoûriya, fundada em 947 pelo terceiro califa fatímida. Ao Sul do Magrebe, surgiram na entrada do deserto as grandes cidades caravaneiras, pontos de chegada do ouro do Sudão: Sidjilmâsa, Ouargla, as cidades do Mzab, Ghadames, etc. . . . Daí, na outra extremidade das pistas saarianas, o comércio muçulmano introduziu as formas urbanas no mundo sudanês: as cidades do ouro e dos escravos nasceram no Sahel: Awdaghost, Tadmekka, Tombuctu (17). E, em conseqüência, a abertura dêsse imenso horizonte comercial desempenhou um grande papel na restauração urbana que se desenvolveu na Âfrica do Norte muçulmana entre o VIII e XII séculos: renovação urbana mais importante e mais extensa que a urbanização đa região na época romana.

(16). - L. M. Devie, Le Pays des Zendjs ou la Côte orientale d'Afrique au moyen

(17). - E. E. F. Paris, 1883 “L' 'or du Soudan dans 1'histoire" (Annales d'Histoire écono. mique et sociale, VII, 1935). 
Na Espanha, Córdoba, Toledo, Saragoça, Sevilha, Máiaga, centros antigos reduzidos a quase nada durante o período bárbaro, readquiriram vida e fôrça e brilharam como jamais o tinham feito antes. O grande pôrto de Almeria - a "Aumarie" das canções de gesta - foi criado na época muçulmana. Em tôrno de Córdoba, como em tôrno de Cairoão, se levankaram cidades-residências: Madinat az-Zahrâ (936), Madînat az-Zâhira (978-979).

Na Sicília, Palermo tomou impulso, monumental e econôm:camente.

E não citamos aqui senão as metrópoles, as cidades mais importantes. Ao lado delas, uma infinidade de aglomerações urbanas, mais ou menos populosas e que tiveram em seguida sucesso diverso, contribuindo tôdas na ocasião, para aumentar a densidade da rêde urbana (18).

Quais foram os aspectos gerais dessa cidade muçulmana em pleno período de crescimento?

Primeiramente o seu aspecto demográfico. No perímetro urbano, uma grande concentração de população era a regra. Muitas meltrópoles citadas tornaram-se, em algumas dezenas de anos, as maiores cidades do mundo. Na falta de um recenseamento preciso, para têrmos uma ordem de grarideza, devemos levar em conta que temos pela frente não casas baixas, dispostas espaçadamente, mas sim pelo contrário, àquilo que os latinos chamavam de insulae: grandes blocos de casas de sete ou oito andares, onde viviam até 250 e 300 pessoas, como nossas fontes o indicam expressamente para o Cairo, Bagdá, no fim do IX e no X século, - ssu período de apogeu -, atingiu e passou certamente mesmo a cifra de um milhão de habitantes. Sua superfície urbana se inscrevia nos limites de Paris das fortificações (ou boulevards exteriores). Damasco e Córdoba, apresentavam aglomerações de trezentos a quatrocentos mil habitantes. O Cairo devia contar um pouco mais, cêrca de meio milhão. Se colocarmos face a face êsses algarismos - que são, repetimos, meras aprcximações - e aquêles que podemos atribuir às cidades do Ocidente por ocasião de seu pleno desenvolvimento econômico, isto é, no XIII século, só se pode fi-

\footnotetext{
(18). - Algumas monografias de grandes centros urbanos muçulmanos - de desigual interêsse para o historiador das cidades - já foram estampadas. Citamos: G. L. Strange, Baghdad during the Abbasid Caliphate, Oxford, 1900; E. Herzfeld, Geschichte der Stadt Samara (Die Ausgrabungen von Samarta, VI, Hamburgo, 1948); J. Sauvaget e J. Weulersse, Damas, Paris, 1936; J. Sauvaget, Alep, essai sur le développernent d'ne grande ville syrienze des origines au milieu du XIXe siècle, Paris, 1941; M. Clerget, Le Caire, étude d'histoiro et de géographie urbaines, Paris, 1934; R. Le Tourneau, Fếs avant le Protectorat, étude économique et sociale d'une ville de l'occident musulman (Publ. de l'Institut des Hautes Etudes marocaines, Casablanca, 1950); $G$. Marçais, Tunis et Kairouan, Paris, 1937; R. Castejón, "Córćoba califal" (Boletin de la. Reel Academia de Córcioba, 1924); R. Velásquez Bosco... "Excavaciones en Mdina Azzahra" (Junta Superior de excavaciones y antiguedades, 1923-1924 e seguintes).
} 
car admirado da diferença enorme que as separavam: as cidades mais populosas da Itália do Norte ou da Flandres não possuiam então mais que trinta ou quarenta mil habitantes, e foi necessário atingir o século XIV para que Paris, cidade única no Ocidente cristão, atingisse trezentas mil almas. Coloquemos Bizâncio de lado, que se aproxima certamente do milhão de habitantes, que era uma cidade do Oriente e a grande rival de Bagdá. "Bagdá e Bizâncio, os dois olhos do mundo", como diziam os historiadores bizantincs que reconheciam assim a preeminência da capital dos Califas.

Se considerarmos agora o aspecto econômico e social dessas grandes cidades muçulmanas, verificaremos que elas são antes de mais nada centros de comércio. $E$ isso se refletia no próprio plano da cidade. No meio, e muitas vêzes atravessando-a de um lado a outro, se estendia o soûq, o mercado, a rua comerciante e industrial onde os objetos eram fabricados e postos à venda sob os próprics olhos do cliente. Ainda hoje os soûqul das grandes cidades do Oriente e do Magrebe disso nos dão uma imagem fiel. No meio do soûq erguia-se uma grande mesquita, centro moral do mercado, cuja sombra protegia e tornava mais honestas as transações. Ao lado estavam dispostas os fondoûqs, hospedarias para os mercadores e a kaisaria, grande mercado fechado com pesadas portas reccbertas de ferro, que servia de entreposto para as preciosas mercadorias oriundas do exterior. Em frente da kaisaria, encontravase o soûq as-laghâ, o mercado das trocas, e, se a cidade tinha bastante importância, o palácio da Moeda, o dat as-siqqâ. Em tôrno dêsse núcleo central de organismos comerciais, estavam instalados as diferentes corporações de ofício, agrupadas cada uma de acôrdo com o seu bairro, em sua ruz própria. O sồq, polo da atividade urbana, mantinha uma população industriosa e comerciante, de vida pululante e turbulenta, desde o carregador, o artífice, o corretor, até o grande comerciante, dominador do mercado. Então criou-se o tipo do ccmerciante por atacado, enriquecido no comércio longínquo, vivendo luxuosamente no seu opulento palácio urbano, no meio de uma turba de escravos e de familiares, os "patrícios do Islão", "armadura de dinheiro" da sociedade urbana do mundo muçulmano. Ao mesmo tempo também aumentava a miséria das camadas baixas da população citadina, escravos ou livres, plebe urbana cujas revoltas às vêzes eram terríveis: no inícic do IX século, os "nus" se tornaram senhores das ruas de Bagdá e saquearam muitos bairros da capital. Efervescência social, oposição brutal, que mostrava a intensidade da vida urbana dessa época.

Um último aspecto da expansão urbana no mundo muçulmano do VII ao XI sécuio, ainda para indicar, o menos conhecido e, tal- 
vez, o mais importante, porque nos sugere elementos de explicação: o aspecto monetário. A moeda era, com efeito, o medium pelo qual se criou, se manteve e também se caracterizou melhor essa poderosa atividade urbana: construção material da cidade e grande apêlo de mão-de-cbra para as oficinas; compras de víveres no campo para o consumo corrente e mercadorias preciosas nos centros de produção afastados para o consumo de luxo; fabricação e venda in-loco ou ao longe dos produtos da indústria local; compra pela classe rica de bens territoriais no campo... Na economia geral, o mercado urbano era um centro privilegiado de atração e de redistribuição das massas monetárias. E, por sua vez, a expansão urbana do mundo muçulmano foi possível e foi suportável pelo afluxo do ouro e a sua circulação cada vez mais intensa: ouro entesourado posto em circulação e, sobretudo, afluxo de ouro novo, de ouro de mina e mais particularmente de ouro sudanês, cujo volume aumentou à medida que avançamos no tempo, a partir dos séculos VIII e IX. O fato capital para a história do movimento urbano durante a Alta Idade Média, foi a reintrodução de grandes cidades, isto é, importantes centros de consumo, no Mediterrâneo ocidental onde a decadência urbana se acentuava desde o Baixo-Império: Cairoão, Fez, Córdoba, Palermo. Esse movimento da urbanização profunda, de vida citadina, de civilização e de irradiação urbana alcançou, nos séculos IX e X, o Mogrebe, a Espanha e a Sicília; êle foi criado pela onde de ouro que chegava do Sudão. As regióes do Islão ocidental - que os autores árabes englobam sob o nome de Magrebe ("terras do Ocidente") -, eram para os orientais, um verdadeiro Eldorado que atraia aventureiros, mercenários, literatos, em busca de ouro, de prebendas e de pensões. Foi o ouro do Sudão que fêz afluir na Andaluzia, do Oriente, sobretudo de Bagdá que é o grande centro de irradiação, os poetas de côrte, os músicos, os artistas, aquêles que foram chamados de pioneiros da cultura oriental (19), e graças aos quais as técnicas, as formas de pensamento refinado, a civilização urbana em uma palavra, passaram do Oriente para o Ocidente muçulmano, às portas do Ocidente bárbaro.

O apêlo ao consumo lançado pelas grandes cidades do mundo muçulmano permitiu ao comércio e ao movimento urbano propagar-se e desenvolver-se no Ocidente bárbaro como se tinha produzido, como já vimos, na África Negra. Os centros urbanos muçulmanos tiveram necessidade de certas mercadorias que sòmente 0 Ocidente bárbaro lhes podia fornecer (escravos, metais, madeira, peles) e, em troca deșsas mercadorias, enviaram ouro. Houve uma

(19) . - Cf. R. Blanchère, "Un pionnier de ta culture arabe en Espagne au Xe siècle, Sâ'id de Bagdad" (Hespéris, X, 1930). 
infiltração de ouro no Império carolíngio e nas regiões circunvizinhas, assim como desenvolvimento do comércio e renovação do movimento urbano desde os séculos IX e X.

Quando os medievalistas principiaram escrever a história da renovação urbana no Ocidente, começaram por dizer: a renovação urbana foi a conseqüência das Cruzadas; ela se fêz sentir no XII século. Depois, indo mais a fundo no seu estudo, fizeram remontar essa renovação ao século XI. Após, procuraram ainda mais e encontraram indicações mui precisas já para o século $\mathbf{X}$. As pesquisas mais recentes falam do fim do século IX e, em certos pontos muito localizados - que são justamente os pontos onde chegavam as rotas comerciais e monetárias oriundas do mundo muçulmano -, aparecem as primeiras manifestações do reerguimento das cidades, de crescimento urbano, desde o fim do VIII século e o início do IX: ocasião em que o ouro muçulmano, sob a forma do mancus, começou a irrigar o Ocidente bárbaro.

E' assim que desde essa época se desenvolveram as cidades da Itália: Amalfi, Salerno, Nápoles, Gaeta, no mar Tirreno e sobretudo Veneza no Adriático; Veneza que deveu o seu precoce desenvolvimento econômico à sua situação de local do encôntro de três domínios comerciais, de Bizâncio, do mundo muçulmano e do Ocidente bárbaro: ela concorreu para o reabastecimento de Constantinopla, privada pelas conquistas muçulmanas, das provisões que ela tirara até então das suas províncias do Egito e da Síria. Ela fêz frutuoso tráfico de contrabando com os portos muçulmanos. Importou os produtos preciosos da indústria bizantina que difundiu nas feiras de Pavia (20), onde os seus mercadores tinham o monopólio do comércio dos objetos orientais que o Ocidente podia agora adquirir, graças as entradas de ouro muçulmano. Pode-se dizer que os primeiros e rápidos progressos de, Veneza nos séculos VIII e IX foram uma conseqüência, direta ou indireta, das conquistas árabes e do apêlo ao consumo lançado pelos grandes centros urbanos do mundo muçulmano. Não esqueçamos também a posição monetária de Veneza entre o domínio do ouro bizantino e muçulmano e o domínio da prata ocidental, posição que, no século XIV ainda, fêz dela uma grande praça de arbitragem entre a prata e o ouro.

Foi a vez em seguida, das cidades do Norte da Espanha e do vale do Ródano que é continuado pelo Saona, o Mosa, as regióes renanas e a Flandres.

Ao mesmo tempo, da outra extremidade do mundo islâmico, se fêz sentir também o apêlo lançado pelos grandes centros orien-

\footnotetext{
(20). - Sóbre as feiras de Pavia o o comércio veneziano que aí so fazia, vide os Honorantio civitatis Papie, publicados por A. Solmi in "Amministrazione finanziaria nel regno italico nell'alto medio evo" (Bolettino della Societa Pavero di. Storia Patria XXXI, 1931).
} 
tais, criados ou reanimados na época muçulmana e sobretudo Bagdá cuja influência se irradiou e se estendeu. Apêlo lançado ao Ocidente bárbaro, pelas rotas do Norte, rotas do Volga, do Báltico e da Europa central. Por aí também, se infiltraram as moedas muçulmanas. Imensos depósitos delas foram encontradas ao longo dcs rios russos, nas margens do Báltico e até na Islândia. $\mathbf{E}$ a criação de centros comerciais, de embriões de cidades continuou. Também nasceu "o País das cidades", gardariki, como os escandinavos, chegados logo após a essa expansão urbana e atraídos por ela, chamavam a região dos rios russos; cidades de madeira, construídas ao longo dos cursos d'água navegáveis, nos pontos escolhidos pelo grande comércio, nos locais onde desembocavam as correntes de moedas oriundas do mundo muçulmano: Itil (Astracã), sôbre o delta do Volga, Bolgar (no local da futura Cazã), na confluência do Volga e do Kama, a "Cidade dos Burtas" (mais tarde NijniNovgorod), Novgorod a Grande, sôbre o Volkhov, ao Norte do lago Ilmen e sobretudo Kiev sôbre o Dnieper, cujo horizonte comercial englobava o mundo muçulmano a Leste, Bizâncio ao Sul, as regióes germânicas a Oeste e as costas do Báltico ao Norte (21). Pelas rotas continentais da Europa central e pelas rotas marítimas dos mares nórdicos, o influxo comercial e urbano se propagou rumo às regióes renanas, Flandres e Inglaterra onde encontrou as correntes vindas do Mediterrâneo.

Assim, a expansão urbana no Ocidente bárbaro se localizou muito cêdo nas zonas de entrada das correntes monetárias oriundas do mundo muçulmano. Foi o momento em que apareceram os têrmos portus, "local de mercado", vic ou vicus "arrabalde dos mer. cadores", a ccasião em que a cidade ultrapassou as suas estreitas muralhas e quando se constituiram êsses faubourgs comerciantes e industriais. Os traços dêsse crescimento urbano, com a condição de procurá-los nas zonas onde se entrelaçaram as relações comerciais entre o Oriente muçulmano e o mundo bárbaro, podem ser reveladas desde o fim do VIII século (22).

*

Bizâncio, na mesma época, teve uma renovação semelhante que preparou o florescimento dos séculos $\mathrm{X}$ e XI: a segunda idade de ouro da arte bizantina, o apogeu urbano de Constantinopla. Vide os pormenores fornecidos pelo Livro das Cerimônias, a descrição de Constantino-o-Ródio que celebrou as suas belezas no século $X$, as expressōes admirativas do rabino Benjamim de Tudela que a visitou no início do século XII, o pasmo dos Cruzados de

\footnotetext{
(21): - E. Simões de Paula, O Comércio varegure e o Grãc-Principado de Kiev, São Paulo, 1942.

(22). - H. Planitz, "Frühgeschichte der deutschen Stadt" (Zeitschrift der SavignyStiftung für Rechts@eschichte, Germanist. Abt., LXIII, 1943).
} 
1204 quando penetraram na ciciade "de mármore, de sêda e de ouro" (23).

O início dêsse novo renascimento da velha criação constantiniana se colocou no fim do VIII e início do século IX, quando o curo muçulmano, passando pelo Ocidente vem de novo pôr em movimento as indústrias de luxo e oferecendo novos mercados aos prcdutos bizantinos e às marcadorias em trânsito por Bizâncio, e criundas do Oriente muçulmano, rumo ao Ocidente cristão. Aqui, como em Veneza, a frutuosa posição de intermediária entre o mundo orintal e o mundo ocidental e o afluxo monetário que daí resultou foi a origem do renascimento urbano. Por sua vez, Bizâncic exportou uma parte do seu ouro para o mundo muçulmano para aí ađquirir matérias primas rieceseárias ao seu luxo, às suas indústrias, às suas reexportações: especiarias, perfumes, sêda em bruto, marfim, pérolas, pedras preciosas, etc.... E êsse ouro veio sustentar e ampliar ainda mais a atividade das grandes cidades muçulmanas.

Do Oriente muçulmano ao Ocidente muçulmano, do Ocidente muçulmano ao Ocidente bárbaro, do Ocidente bárbaro a Bizâncio, de Bizâncio ao Oriente muçulmano, o circuito é fechado: circuito monetário e circuito urbano.

Geogràficamente e cronològicamente, a evolução urbana da Alta Idade Média cobriu muito exatamente a evolução monetária: afluxo de ouro e renascimento urbano seguem juntos o mesmo caminho.

O mundo muçulmano do VII ao XI século, em que o ouro afluiu, apareceu assim como o centro - e a crigem - dum vasto movimento de renascença urbana que se propagou ao longo das grandes rotas comerciais revivificadas ou novamente criadas pelo apêlo ao consumo partido das metrópoles do Oriente islâmico: arnplificação da expansão urbana no antigo domínio sassânida; reflorescimento das cidades no antigo domínio bizantino, na Espanha ruralizada e na África do Norte nomadizada; progresso de Constantinopla; criação de cidades no mundo negro ( costas da África oriental e Sudão), na região dos rios russos e do Báltico; enfim, reinício da atividade urbana no Ocidente cristão.

Pela sua extensão, sua intensidade e também pela éra nova que êle abriu para a Europa ocidental, êsse movimento marcou uma época capital no desenrolar da história urbana.

\section{MAURICE LOMBARD}

Diretor de estudos na Ecole des Hautes-tudes (Sorbonne, Paris).

(23). - Ch. Diehl, Constantinople, Paris, 1924. Mapa da cidade in A. M. Schneider, Byzanz, Vorarbeiten zu Topoğtaphie und Archäologie der Stadt (Istambuler Forschungen, VIII, Berlim, 1936). 